\title{
Breaking the Shell: Labour Force Participation among Married Women by Ethnic Sub Groups in Sri Lanka
}

Sri Lanka Journal of Social Sciences and Humanities Volume 1 Issue 1, February 2021: 1-11 ISSN: 2773 692X (Online), 27736911 (Print) Copyright: (C) 2021 The Author(s)

Published by Faculty of Social Sciences and Languages, Sabaragamuwa University of Sri Lanka Website: https://www.sab.ac.lk/sljssh

\author{
Siyama, M.A.F. ${ }^{1,{ }^{*}}$ and Samaraweera, G.R.S.R.C. ${ }^{2}$ \\ 1,2 Department of Economics and Statistics, Sabaragamuwa University of Sri Lanka, Belihuloya, 70140, Sri Lanka.
}

Received: 13 November, 2020, Revised: 02 January, 2021, Accepted: 26 January, 2021.

How to Cite this Article: Siyama, M.A.F., \& Samaraweera, G.R.S.R.C. (2021). Breaking the shell: Labour force participation among married women by ethnic sub groups in Sri Lanka. Sri Lanka Journal of Social Sciences and Humanities, 1(1), 1-11.

\begin{abstract}
Gender equality in decent work and economic decision-making are still not ensured in Sri Lanka although it ensures gender parity in both education and health care. Marriage, culture, and traditional values challenge the human right of independent economic decision making among women in developing countries. The main objective of this study is to explore the ethno-specific drivers of Labor Force Participation among married women in Sri Lanka to capture deep insights into the ethno-cultural picture of the issue. Secondary data were used from the Sri Lankan Labour Force Survey 2018 including 14,533 married females and four Binary Logistic Regression models were derived for female labour force participation among ethnic subgroups. The analysis concludes that ethnicity plays a major role in the career contribution of married females in the country. Concerning married Sinhalese women, the married women representing the Sri Lankan/Indian Tamils are more probable to join in the labour market, while married women representing the Moors are less probable to participate as they are highly intertwined to traditional and cultural boundaries. Employment and occupational sector of husband, availability, and age of children, family income, age, residential sector, province, disability, vocational training, and digital literacy are the key drivers of career contribution of married women that reflect distinctive impacts on different ethnic groups. Finally, the study proposed possible policy recommendations for encouraging Female Labour Force participation by addressing the ethno-marital issues.
\end{abstract}

Keywords: Ethno specific factors, Marital status, Women's labour force participation

\section{INTRODUCTION}

The role of human capital is considered as one of the decisive components while making national strategies for sustained growth and development of a developing country (Abraham et al., 2017). Contradictorily, these substantial investments in human capital have not been aligned with increasing women's labour force participation (World Economic Forum, 2016). Though, Sri Lanka provides a wonderful example for gender equality among other South Asian countries (Sarvananthan et al., 2017), the female labour force participation rate remains comparably low while making it a puzzle to many researchers (International Labour Organization, 2016). Samarakoon and Mayadunne (2018) stated that despite gender equality in education is favourable to women; still, most of the working age women in Sri Lanka are staying at home without participating in the labour market. Gunatilaka (2013) argues that females face a number of constraints due to different types of factors when they serve as single women, married and female heads of household in the case of participating in the labour force. This paper will analyse the determinants of married female labour force participation in the country by ethnicity.

Labour force participation rate of women, who live alone, is higher than that of women who live with a partner and kids. According to labour statistics on women (ILOSTAT, 2020), there is a considerable decrease in the Female Labour Force Participation (FLFP) when they are living with partners and kids. The presence of children forces women to be outside of the labour market. As per the statement of US Ambassador Alaina B. Teplitz at a Women Leaders' Business Panel in
2019, women in Sri Lanka currently account only for 35 percent of the workforce. That number is relatively lower when compared to the worldwide average of 47 percent. Therefore, it is very important to study the factors that affect FLFP, to identify the possible policy interventions to encourage females to work. A sharp decline in FLFP is seen with marriage in the region of Arab because marriage increases the home responsibilities of women and forces them to withdraw from the labour market involvement (Baxter, 1997). In common, and particularly in South Asia, it is accepted that social standards have a noteworthy impact on women's choice of career contribution. These standards work at different levels of society, circumstance, religion, caste, and locality (Das and Desai, 2003; Panda, 2003; Göksel, 2012; Jaeger, 2010).

Abraham et. al. (2017) mentioned many standard economic variables that impact FLFP, such as experience, wages, and incomes, education, etc. Apart from this, there are some other non-economic variables such as urbanisation, head of the household's status, land ownership and family size, employment structure and marital status, and fertility. Ajwad and Kurukulasuriya (2002) stated that worker's productive skills, educational attainment, and the number of years of work experience are the key dimensions that influence the FLFP. Additionally, ethnicity and gender are also considered as some important factors. According to Abdulai and Delgado (1999), ethnicity, gender, experience, non-labour income, number of children, age, age-squared to control for the nonlinear life cycle, education and household size are some of the key variables that impact FLFP. Women's Career 
Development, Individual Factors, Family Factors, Organizational Factors, Cultural Factors, Career-Focused, Family Support, Attitudes towards Organization are the broad factors that create the effect of a glass ceiling on women's career development in private sector organizations (Bombuwela and Alwis, 2013).

This study mainly focuses on the Ethnic Specific Drivers of Married Women's Labor Force Participation in Sri Lanka, as Sri Lanka is in a comparatively low position among other South Asian countries (The World Bank Annual Report, 2019). This is a problematic scenario for a country as FLFP is one of the standard measures that are being widely used to measure the development of a country. Both external and internal hindrances should be addressed equally for the successful economic empowerment of women (Sarvananthan et al., 2017). Therefore, it is important to find out the reasons behind the low rate of labor force participation among married women in the country.

In Sri Lanka, only limited studies have discussed the determinants of married women's labor force participation by ethnic subgroups and have attempted to illuminate the difficulties underlying the low rate of female labor force participation when they engage in their married life. The main objective of this study is to identify the drivers of married women's labor force participation decisions among different ethnic sub-groups in Sri Lanka. The specific objectives are, to identify the drivers of married women's labor force participation in Sri Lanka and to identify the factors that affect married women's labor force participation by ethnic sub-groups in Sri Lanka.

\section{LITERATURE AND HYPOTHESES}

Labour force participation is elucidated in many ways through various economic theories. Becker (1973) discusses labour market consequences of both men and women based on the marriage market through the Theory of Marriage concerning two assumptions; that every person tries to achieve as much as can be achieved and this so-called market is working at the equilibrium condition. Men vary in education or intelligence, race, physical capital apart from their effects on the wage rate, height, or any other attributes and will tend to marry women with like values of those characteristics, whereas the association between spouses for wage rates or for traits of male and female that are close replacements in household production, will be negative.

Becker (1965) explains the market and non-market activities by presenting the Theory of the Allocation of Time among unalike activities in detail. One of the concepts indicated in the theory is dividing the labour among the members of the family. If it is a multi-person Household $(\mathrm{HH})$, the time will be efficiently allocated among the members rather than simply assigning among commodities. That means the time allocation of a member in the $\mathrm{HH}$ will greatly be affected by the chances open of other members in $\mathrm{HH}$. According to The Labour-Leisure Theory, when wages rise, people accept an increased time cost of taking care of children, but also meet with inflated incomes (Aaronson et al., 2017). Further, the theory postulates that the reason for individuals and households entering the labour market is the need for higher income, and they work long hours till the benefits of market works exceed the household activities. Wage rate and nonlabour income are the main economic variables impacting the availability of labour or the allocation of an individual's time between leisure and work (Abraham et. al. (2017).
Ethnicity and Marital Status on FLFP: Van Hedel et. al. (2015) have discussed the relationship between marital statuses and labor force participation in their study while using marital status, labor force activity, and mortality through a study in the USA and six European countries. Using related statistics they proved that there is a considerable difference among countries when it comes to the marital statuses and labor force participation within the population distribution. The majority of the literature has mainly given higher importance to women's labor force participation in developing countries for married women (Oppong, 1983; Wong and Levine, 1992; Doan and Popkin, 1989; Michalopoulos et al., 1992) since single women enjoy a considerably higher rate of employment as compared to married women (Panda, 2003). Baxter (1997) discusses the participation in HH work of people based on gender. He stated that females experience a higher amount of $\mathrm{HH}$ work compared to males and it seems to be a common phenomenon all over the world. A sharp decline in FLFP is seen with marriage in the Arab region. However, it rises where older, divorced, or separated and widowed women are concerned. Marriage leads to increased home responsibilities for women and forces them to withdraw from the labor market involvement. Marital status has been defined in different aspects by different scholars. A woman's legal status appeared statistically significant, indicating that the legal status perhaps was a crucial factor influencing the labor pool participation of a woman (Samarakoon and Mayadunne, 2018). On the contrary, Hussain et. al. (2012), Khan and Khan (2009), Grimm and Bonneuil (2001), and Faridi et. al. (2009) argue that there are neither positive nor negative relationships that exist between them. In traditionalist social orders, ladies have less freedom to select their accomplices, creating a lesser bartering control within the family. In a sense, instead of their fathers, they had to comply with their spouses after marriage (Göksel, 2012). When considering the Sri Lankan situation, Samarakoon and Mayadunne (2018) indicate that, when it comes to the occurrence of stopover at home, the uppermost is the females who are married and have children.

There are plenty of theories that discuss the determinants of labor supply of females, such as Becker (1973), Becker (1965), Neo-Classical Labor Leisure Model: Aaronson et. al. (2017), Azid et. al. (2001), etc. However, most of the popular theories examine the factors related to women's job contribution in a general context. Very few theories are based on their ethno and marital specific determinants. This study expects to scrutinize how the ethno specific drivers affect the married female's labor force participation and hope to provide a better contribution to fill this theoretical and empirical gap in the literature.

Social components constrain women's rights within the work environment and their engagement in work. Religion still includes a key part in deciding the sex standards in numerous nations (Pastore and Tenaglia, 2013). Economic, social, and political welfare factors directly influence female labour force participation through several aspects in the case of developing countries (Hussain et al., 2012). Females do not make choices in segregation, but the situations they livein affect their conduct. Ladies in preservationist and conventional situations where men have a higher choice control, and which have more grounded social standards tend to remain at domestic, as expected by society, and gotten to be housewives (Göksel, 2012). Ethnical influence on female career contribution is confirmed by Samarakoon and Mayadunne (2018), Gunatilaka (2013) and Gunatilaka and 
Vithanagama (2018), Tansel (1998), Hussain et. al. (2012), and Kulatunga (2014). Therefore, the study assumes that;

\section{H1: Ethnicity has an impact on married FLFP}

Household Factors on Married FLFP: Horrell and Humphries (1995) stated that inside most narratives of women's expanding economic dependence on men, there's room to find pockets of change and freedom clearly related to industrial opportunities. Distinctive relationship between hitched women's employment and their husband's work-related status are discussed by Panda (2003). Al-Qudsi (1995) indicates that females show a lower participation rate in labour market when they have children of school-going age. Having children serves as a negative relationship with the FLFP. However, when they have children below two years, it increased the chance for women to join the labour market (Horrell and Humphries, 1995; Göksel, 2012).

Gunatilaka (2013) explains the female labour force participation in Sri Lanka and suggests that having domestic help seems to significantly permit a female to contribute to a job. Panda (2003) identifies the effect of six categories of dependants in the family on FLFP for married women. However, the number of same era men appears as a solid negative impact on single women's employment. Be that as it may, these factors are unimportant to the employment of hitched ladies.

Arellano and Meghir (1992) found that when males are educated, it reduces the chances of participation of women in the labor market. This is confirmed by Leibowitz and Klerman (1995) and Shah (1986) as well. Weerasinghe and Parr (2002) argue that after controlling other factors, higher levels of family riches were associated with lower income. There were too critical impacts in support of female labor force, ethnicity, age-at-marriage, and equality on current income. In any case, after controlling the wealth and other informative factors, the impact of female instruction was not noteworthy. In case the proof was to remain steady over time, rising levels of riches would diminish conjugal richness in Sri Lanka. Thus, the study can predict that;

\section{H2: $H H$ factors have an influence on married FLFP}

Socio-Economic Factors on Married FLFP: According to Hussain et. al. (2012), there is a significant and positive connection between the age of the respondent and the contribution of females in paid jobs. It is confirmed by many research studies, such as Khan and Khan (2009); Ejaz (2007); Contreras et. al. (2005); Azid et. al. (2001); Naqvi and Shahnaz (2002). One of the main reasons for the frequent decrease in FLFP within the recent past is urbanization (Ilkkaracan, 1998). According to the findings of Göksel (2012), in-country regions ladies traditionally work, whereas this is usually not the case in cities because convention and men's higher bartering power play a negative part within the likelihood of ladies working in urban areas. Samarakoon and Mayadunne (2018) and Gunatilaka (2013) explain the provincial influences on female labour force participation in Sri Lanka. Sarvananthan et. al. (2017) mentioned that high unemployment prevailed in conflict-affected areas of Sri Lanka.

Education is positively related to female labor force participation (Samarakoon and Mayadunne, 2018). The importance of education for women has recently changed women's attitudes, including their higher education attainments, increasing labor force participation, and reducing the family size (Mason et al., 1976; Thornton and Freedman, 1979). Semasinghe (2017) identified disability as one of the reasons for the non-participations of females in the job market in Sri Lanka. The economic growth of a country highly depends on literacy and education (Barro, 1998) as well as women's education (Klasen, 2002). All individuals in any case of sex in our society must at least obtain fundamental ICT abilities to operate effectively and productively, to improve and succeed in their professional lives (Palma, 2001; Trauth, 2002; Wynarczyk et al., 2006). Burki and Fasih (1998) explain that vocational training serves as a notable and positive influence on paid work.

The least number of studies have used some unique and chronologically relevant drivers (eg. digital literacy, disability, vocational training) of female job contribution even to a lesser extent. This study hopes to generate meaningful findings to understand the ethno specific drivers of married female labor force participation in the country by filling these empirical gaps in the literature. Based on the above literature, the following hypothesis is presented for the study;

H3: Socio-economic factors have an influence on married FLFP

\section{MATERIALS AND METHODS}

According to the viewpoint of the objective of this study, this research is related to the exploratory type, since the study tries to explore what FLFP and its ethno and marital specific determinants are. In line with the viewpoint of the mode of inquiry, this research is based on the quantitative approach as it uses numerical measurements. When it comes to the mode of thinking, this research is categorized under the deductive mode as it uses the theory testing approach. Here, the mental assumption is considered for the selection of data collection and the way of accepting the assumption by the researcher. This research undertakes the positivism paradigm as it uses the quantitative approach to measure the selected variables. A similar approach has been used in previous studies by Samarakoon and Mayadunne (2018), Madurawala (2009), Gunatilaka (2013), and many others.

To achieve the hypotheses, the study uses secondary sources to collect needed data from the Annual Labor Force Survey 2018, which is one of the nationally accepted sources of collecting secondary data. The population for this study is married females in the working-age population; all married females of age 15 years and above in the country. The economically active populace at present (labor force) is typically recognized as the addition of the "employed" and "unemployed" populace.

The sample frame is prepared based on the 2012 Census of Population and Housing using the technique of two stages stratified sampling procedure for the total sample size of 14,533 married females living with their spouses of age 15 years and above, covering all provinces of the country in 2018, ethno-specific subsamples were created as Sinhalese $=10,196$, SL and Indian Tamil $=2,788$ and Moor $=1,404$. Only married females who live with their husbands have been selected for the model to achieve efficient findings related to household factors.

$$
\begin{aligned}
L i=\ln \left[\frac{P i}{1-P i}\right]= & \text { Logit }(Y) \\
& =\beta_{0}+\beta_{1} D_{1-2}+\beta_{2} X_{1-2}+\beta_{3} D_{3-20} \\
& +\beta_{4} X_{3-5}+\beta_{5} D_{21-27}+\varepsilon
\end{aligned}
$$

$\mathrm{Pi}=$ Probability of being participated in the labour force, 1 $\mathrm{Pi}=$ Probability of not being participated, $\beta 0=$ Intercept, D1$2=$ Ethnicity, $\varepsilon=$ Error term

Effect of household factors: Family Income (X1), Household size (X2), Employment sector of husband (D3-5), Occupational sector of husband (D6-13), Availability of children 
(D14-16), Availability of domestic servant (D17), Education of husband (D18-20)

Effect of socio-economic factors: Age (X3), Age square (X4), Educational attainment (X5), Living sector (D21), Province (D22-24), Disability (D25), Digital literacy (D26), Technical Training (D27)

The 2018 LFS secondary microdata is analyzed using the STATA/MP 13(64-bit) statistical package software removing heteroscedasticity within the variables through the robust command and the Binary Logit Regression analysis is used to identify the influence of the factors that affect married female's labor force participation based on ethnicity. The Dependent variable: of this study is Labor force participation of married women $(Y)$ which is a dummy variable to check whether a married woman participated or not in the job market. Independent variables $(\mathrm{X})$ includes two categories as household factors: Household size, Family income, Employment and Occupational sector of the husband, Availability of children, Availability of domestic help and Education of husband, Socio-economic factors: Ethnicity, Age, Age square, Educational attainment, Living sector, Province, Disability, Digital literacy, and Technical Training.

Here, household size is a continuous variable, generated using the household indexes counting the number of members in a household. Family income means, the total income of a family including both labour and non-labour income coming from both primary as well as secondary income sources of the household head and his spouse. There are main $4 \mathrm{em}$ ployment statuses included in the model; employee, employer, own-account worker, and unpaid family workers. Eight occupational sectors were considered in the study as service, managerial, professional, technician, clerical, service, agricultural, elementary, unidentified, and separate dummies were created each of the variables to know whether their husband belongs to that particular sector not. Children are defined as sons and daughters of household heads in the data set. This variable is categorized into 4 groups as do not have children, availability of children less than 6 years, availability of children between 6 and 15 years, availability of children more than 15 years old. Availability of domestic help is a dummy variable and Education of $\mathrm{HH}$ head consists of four dummy variables as Non-schooling (Not schooled), Primary (passed grade 1 to grade 5), Secondary (passed grade 6 to grade 13), and Tertiary (passed G.A.Q/G.S.Q, Degree, Post Graduate Degree/Diploma, Special educational institutions). Age, age squared and educational attainment are continuous variables. The residential sector included as a dummy whether the women belong to an urban sector or non-urban sector. The non-urban sector includes both rural and estate sectors. All nine provinces (Western Province, Central Province, Southern Province, Eastern Province Northern Province, North Western Province, North Central Province, Uva Province and Sabaragamuwa Province) are categorized into 4 major groups as, Western provinces, Agriculture and plantation-based provinces (Central Province, Sabaragamuwa Province, Uva Province and North Central Province), Industrial based provinces (Southern Province and North Western Province), Post-war provinces (Eastern Province and Northern Province). Separate dummies were generated for each of these categories. Finally, Disability, Digital literacy, Literacy- languages, and Vocational training are created as general dummy variables with dichotomous expressions.

\section{RESULTS AND DISCUSSIONS}

Labour force participation rates of married women by ethno specific subgroups (Sinhalese, SL and Indian Tamil, and Moor) are given in Figure 1. Sinhalese women associate with the highest rates of participation (39.03 per cent), as they have less cultural and social barriers against their participation. SL and Indian Tamil women contribute almost the same proportionate share as the second highest value. In general, Tamil women are highly specialized in performing plantation-based economic activities. Regarding Moor women, around $80 \%$ of married women are not participating in any employment opportunities because they are subjected to follow higher social and cultural restrictions that keep them away from the labour market, as found by Gunatilaka (2013) and Samarakoon and Mayadunne (2018).

Figure 1: Married Female Labour force participation by ethnic subgroups

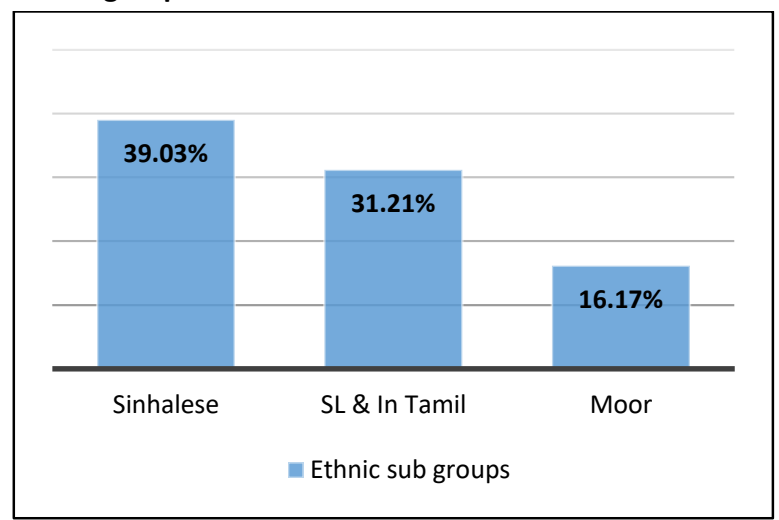

Source: Developed by the researcher using LFS 2018 data

Data analysis has been done through several steps as it includes four models as the overall model, ethno specific submodels (Sinhalese, SL and Indian Tamil and Moor). All the models are compared based on the determinants of Labour force participation of married women in 2018. Table 1 presents the marginal effects of binary logistic estimation and the $p$-value of the variables which presents the significance level of the results.

Before discussing the results of the probability analysis, it is important to bear in mind that, only the married spouses living with husbands are selected for the sample to observe the family context where the labour supply decisions are jointly taken based on the Household Model of Labour Supply.

Ethnicity is categorized as Sinhalese, Sri Lankan and Indian Tamil, and Moor; other ethnic groups are dropped due to insufficient cases and Sinhalese is considered as the base category. Both Tamil and Moors are highly significant with distinct responsiveness. Sri Lankan and Indian Tamil women are more likely to engage in the labour market compared to the base category by around 7.5 per cent. In general, the majority of the plantation and agricultural sectors operate with a higher participation rate of SL and Indian Tamil women who belong to the estate and rural sectors. Because of that, they have been accustomed and skilled culturally and traditionally in doing these plantation and agriculturalbased employment activities for a long time as well as they are well specialized in these particular fields. Further, they are better encouraged by the incentives like accommodation and other childcare facilities provided by plantation employers. These aspects motivate them to better participate in the labour market. Nevertheless, regards to the Moors, the likelihood of participation is lower by around 14 per cent when compared to the reference category. The main reason 


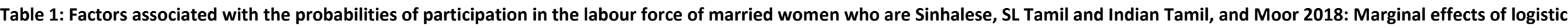
estimations.

\begin{tabular}{|c|c|c|c|c|c|c|c|c|}
\hline \multirow[b]{3}{*}{ Factors and variables } & \multicolumn{2}{|c|}{ Model 1} & \multicolumn{2}{|l|}{ Model 2} & \multicolumn{2}{|l|}{ Model 3} & \multicolumn{2}{|l|}{ Model 3} \\
\hline & \multicolumn{2}{|c|}{ Overall Model } & \multicolumn{2}{|c|}{ Sinhalese } & \multicolumn{2}{|c|}{$\begin{array}{c}\text { SL and Indian } \\
\text { Tamil }\end{array}$} & \multicolumn{2}{|l|}{ Moor } \\
\hline & Marg. Coef & $P>z$ & Marg. Coef & $P>z$ & Marg. Coef & $P>z$ & Marg. Coef & $P>z$ \\
\hline No.obs & 14533 & & 10196 & & 2788 & & 1404 & \\
\hline \multicolumn{9}{|l|}{ Married women labour force participation (y) } \\
\hline \multicolumn{9}{|l|}{ Ethnicity $\left(D_{1-2}\right)$} \\
\hline SL and Indian Tamil $\left(D_{1}\right)$ & $0.075^{* * *}$ & 0.000 & N/A & N/A & N/A & N/A & N/A & N/A \\
\hline Moor $\left(D_{2}\right)$ & $-0.140^{* * *}$ & 0.000 & N/A & N/A & N/A & N/A & N/A & N/A \\
\hline \multicolumn{9}{|l|}{ Household Factors } \\
\hline Family Income $\left(\mathrm{X}_{1}\right)$ & $-0.0001^{* *}$ & 0.011 & 0.00003 & 0.237 & $-0.219^{*}$ & 0.062 & 0.112 & 0.321 \\
\hline Household size $\left(X_{2}\right)$ & $-0.017^{* * *}$ & 0.000 & $-0.013^{* *}$ & 0.004 & $-0.029^{* * *}$ & 0.000 & 0.009 & 0.240 \\
\hline \multicolumn{9}{|l|}{ Employment sector of husband $\left(D_{3-5}\right)$} \\
\hline Employee $\left(D_{3}\right)$ & $0.048^{* *}$ & 0.001 & $0.062^{* *}$ & 0.001 & 0.012 & 0.711 & 0.024 & 0.467 \\
\hline Own account worker $\left(D_{4}\right)$ & $0.079^{* * *}$ & 0.000 & $0.110^{* * *}$ & 0.000 & -0.015 & 0.653 & $0.061^{*}$ & 0.060 \\
\hline Unpaid family worker ( $\left.D_{5}\right)$ & $0.206^{* * *}$ & 0.000 & $0.244^{* * *}$ & 0.000 & N/A & N/A & N/A & N/A \\
\hline \multicolumn{9}{|l|}{ The occupational sector of husband $\left(D_{6-13}\right)$} \\
\hline Managerial sector $\left(D_{6}\right)$ & $0.056^{* *}$ & 0.001 & $0.072^{* *}$ & 0.001 & 0.024 & 0.565 & -0.002 & 0.947 \\
\hline Professional $\left(D_{7}\right)$ & $0.105^{* * *}$ & 0.000 & $0.102^{* *}$ & 0.002 & 0.036 & 0.499 & $0.095^{*}$ & 0.075 \\
\hline Technician ( $\left.D_{8}\right)$ & $0.046^{* *}$ & 0.018 & 0.031 & 0.182 & 0.063 & 0.181 & 0.056 & 0.165 \\
\hline Clerical $\left(D_{9}\right)$ & 0.024 & 0.448 & 0.034 & 0.349 & -0.033 & 0.679 & N/A & N/A \\
\hline Agricultural $\left(D_{10}\right)$ & $0.099^{* * *}$ & 0.000 & $0.105^{* * *}$ & 0.000 & 0.027 & 0.453 & $0.102^{* *}$ & 0.005 \\
\hline Production $\left(D_{11}\right)$ & $-0.029^{* *}$ & 0.044 & $-0.044^{* *}$ & 0.014 & -0.020 & 0.555 & -0.002 & 0.962 \\
\hline Elementary $\left(D_{12}\right)$ & $0.057^{* * *}$ & 0.000 & 0.022 & 0.258 & $0.064^{* *}$ & 0.058 & $0.064^{*}$ & 0.054 \\
\hline Unidentified $\left(D_{13}\right)$ & $-0.118^{* *}$ & 0.049 & $-0.129^{*}$ & 0.058 & $\mathrm{~N} / \mathrm{A}$ & N/A & N/A & $\mathrm{N} / \mathrm{A}$ \\
\hline \multicolumn{9}{|l|}{ Availability of children ( $\left.D_{14-16}\right)$} \\
\hline Having children less than 6 years $\left(D_{14}\right)$ & $-0.067^{* * *}$ & 0.000 & $-0.078^{* * *}$ & 0.000 & $-0.047^{*}$ & 0.071 & -0.015 & 0.595 \\
\hline Having children 6 to14years $\left(D_{15}\right)$ & 0.007 & 0.462 & -0.006 & 0.652 & $0.052^{* *}$ & 0.010 & 0.011 & 0.646 \\
\hline Having children more than 15 years old $\left(D_{16}\right)$ & 0.002 & 0.820 & -0.003 & 0.813 & -0.027 & 0.221 & -0.029 & 0.262 \\
\hline
\end{tabular}

\section{Ethnicity $\left(D_{1-2}\right)$}

Moor $\left(D_{2}\right)$

$0.075^{*}$

0.000

$\mathrm{N} / \mathrm{A}$

Household Factors

Family Income $\left(X_{1}\right)$

Household size $\left(X_{2}\right)$

Employment sector of husband ( $\left.D_{3-5}\right)$

Employee $\left(D_{3}\right)$ 


\begin{tabular}{|c|c|c|c|c|c|c|c|c|}
\hline Having a domestic servant $\left(D_{17}\right)$ & 0.088 & 0.154 & 0.075 & 0.311 & N/A & $\mathrm{N} / \mathrm{A}$ & $\mathrm{N} / \mathrm{A}$ & N/A \\
\hline \multicolumn{9}{|l|}{ Education of husband ( $\left.\mathrm{D}_{18-20}\right)$} \\
\hline Primary $\left(D_{18}\right)$ & $-0.051^{*}$ & 0.054 & -0.056 & 0.137 & -0.058 & 0.189 & 0.010 & 0.884 \\
\hline Secondary $\left(D_{19}\right)$ & $-0.113^{* * *}$ & 0.000 & $-0.120^{* *}$ & 0.001 & $-0.124^{* *}$ & 0.007 & -0.033 & 0.644 \\
\hline Tertiary $\left(D_{20}\right)$ & 0.009 & 0.786 & 0.004 & 0.937 & 0.022 & 0.751 & 0.011 & 0.899 \\
\hline \multicolumn{9}{|l|}{ Socio Economic Factors } \\
\hline Age $\left(X_{3}\right)$ & $0.044^{* * *}$ & 0.000 & $0.053^{* * *}$ & 0.000 & $0.038^{* * *}$ & 0.000 & $0.024^{* *}$ & 0.003 \\
\hline Age square $\left(X_{4}\right)$ & $-0.0005^{* * *}$ & 0.000 & $-0.0006^{* * *}$ & 0.000 & $-0.0005^{* * *}$ & 0.000 & $-0.0003^{* *}$ & 0.005 \\
\hline Educational attainment $\left(\mathrm{X}_{5}\right)$ & $0.004^{* *}$ & 0.006 & 0.002 & 0.410 & $0.012^{* * *}$ & 0.000 & $0.011^{* *}$ & 0.005 \\
\hline \multicolumn{9}{|l|}{ Living sector } \\
\hline Non-urban $\left(D_{21}\right)$ & $0.056^{* * *}$ & 0.000 & $0.041^{* *}$ & 0.006 & $0.107^{* * *}$ & 0.000 & $0.063^{* *}$ & 0.009 \\
\hline \multicolumn{9}{|l|}{ Province $\left(D_{22-24}\right)$} \\
\hline Agriculture or Plantation base provinces $\left(D_{22}\right)$ & $0.090^{* * *}$ & 0.000 & $0.081^{* * *}$ & 0.000 & $0.153^{* * *}$ & 0.000 & $0.065^{*}$ & 0.060 \\
\hline Industrial base provinces $\left(D_{23}\right)$ & $0.050^{* * *}$ & 0.000 & $0.045^{* *}$ & 0.001 & $0.101^{*}$ & 0.076 & $0.082^{* *}$ & 0.021 \\
\hline Post war provinces $\left(D_{24}\right)$ & $-0.178^{* * *}$ & 0.000 & $-0.124^{* * *}$ & 0.000 & $-0.183^{* * *}$ & 0.000 & 0.009 & 0.782 \\
\hline \multicolumn{9}{|l|}{ Disability } \\
\hline Having any Disability $\left(D_{25}\right)$ & $-0.036^{* *}$ & 0.002 & $-0.029^{* *}$ & 0.037 & -0.045 & 0.108 & -0.036 & 0.223 \\
\hline \multicolumn{9}{|l|}{ Digital literacy } \\
\hline Having Digital literacy $\left(D_{26}\right)$ & $0.105^{* * *}$ & 0.000 & $0.109^{* * *}$ & 0.000 & $0.111^{* * *}$ & 0.000 & $0.078^{* * *}$ & 0.000 \\
\hline \multicolumn{9}{|l|}{ Technical Training } \\
\hline Having technical training $\left(D_{27}\right)$ & $0.131^{* * *}$ & 0.000 & $0.131^{* * *}$ & 0.000 & $0.189^{* * *}$ & 0.000 & $0.147^{* *}$ & 0.001 \\
\hline
\end{tabular}

1. (D) and (X) indicate the dummy and continuous variables respectively.

2. The omitted categories in the overall model (Model 1) are Sinhalese; Employer; Service sector worker; Not having children; Not having a domestic servant; Non-schooled husband; urban; Western

province; Not disabled; Not digitally literate; Not technically trained.

2. The omitted categories in the Sinhalese model (Model 2) are: Employer; Service sector worker; Not having children; Not having a domestic servant; Non-schooled husband; urban; Western province; Not disabled; Not digitally literate; Not technically trained.

3. The omitted categories in SL and Indian Tamil model (Model 3) are Employers and unpaid family workers; service or unidentified sector worker; Not having children; Non-schooled husband; urban; Western province; Not disabled; Not digitally literate; Not technically trained.

4. The omitted categories in the Moor model (Model 4) are: Employer and unpaid family worker; worker in the Service sector, clerical or unidentified sector worker; Not having children; Non-schooled husband; urban; Western province; Not disabled; Not digitally literate; Not technically trained.

4. ${ }^{* *}, * *$, and ${ }^{*}$ designate statistical significance at one per cent, five per cent and ten per cent levels respectively.

5. N/A denotes that values are not applicable may be due to insufficient cases.

Source: Developed by the researcher using LFS 2018 data 
for their negative responsiveness seems to be their cultural and traditional values and practices that they follow. Women are highly restricted by their husbands to be at home without going outside and this forces them to stay out from the job market. The implication is that even marriage is not a crutch that can change the cultural restrictions of Moor women. Göksel (2012) denoted that instead of their fathers, they had to comply with their spouses after marriage. Some similar findings have been presented by Samarakoon and Mayadunne (2018) as well.

The probability of participation of married women is significantly influenced by most of the $\mathrm{HH}$ factors selected in the study. Household size negatively impacts the married women's workforce participation decisions among Sinhalese and Tamil ethnic groups. When the number of dependents (children, elders) increases in a family, women have more responsibilities to look after them. Further, if there are many employed male members (employed children) in the family, then there is no need for married women to be employed as they enjoy considerable family incomes. Thus, married women are more likely to reduce their participation when the size of the household increases. The presence of one or more other seasoned relatives within the family includes a solid negative effect on hitched women's business. The older folks dwelling with a couple prevent hitched women's cooperation in paid work (Panda, 2003).

Increasing family income also seems to marginally lower the likelihood of married women's labour force participation. Here, family income includes the husbands' income which is a form of non-labour income to the wife. This would cause to reduce the participation of the wife as she engages in more leisure. Near findings have been suggested by Gunathilaka (2013) in her study.

When considering the influence of employment and occupational sector of the husband on labor force participation of their spouses in the overall model and the Sinhalese model; if the woman is a wife of an employee or unpaid family worker or an own-account worker, then she is more likely to participate in paid jobs, when comparing to a wife of an employer. It is important to note that the wives of Sinhalese unpaid family workers contribute by around 25 per cent of higher participation concerning the base category. Likewise, Moor women are more likely to participate if their husband is an own-account worker. It seems that when the husband does not earn or earns a lower income, their wives are forced to join in a paid job to fulfill their basic necessities.

Regarding the occupational sector of the husband, the majority of the variables are significant in the overall model. When it comes to ethnic differences, if the husband is in a managerial, professional, or agricultural sector, then Sinhalese women are more likely to participate than the reference group of the service sector. When the husband of a Moor married woman is in a professional sector, then her probability of participation is positive. These findings suggest that, when husbands are in higher positions, they marry a woman with equal social status as they like to maintain good social standards and better family backgrounds. Therefore, they do not hesitate to send their wives for better employments which adds dignity to their social status. Also, it helps their children to be a part of a non-competitive group within the labor market. Similarly, married women participate in the job market not only for social dignity but also to earn additional income for the family. This is because when the husbands are occupied in sectors like Elementary and Agriculture, there are more probabilities of their wives, within most ethnic groups, participating in the labor market as insufficient income enables the higher participation of married women. In addition, the agricultural sector includes substitute work where husband, wife, and other family members work together. Contrastingly, Sinhalese married women are less likely to participate when their husbands work in the fields of production or other unidentified sectors. The production sector is one that always functions with tight and busy work schedules and long working hours. Thus, the husbands do not engage much in the family environment and they expect their wives to be at home taking care of other family dependents. Panda (2003) argues that there is a distinctive relationship between hitched women's employment and their husband's work-related status. Since skilled/professional spouses are superior associated with official and systematic channels of work procurement, their spouses will be in a better position to get occupations.

The availability of pre-school children seems to be a constraint for the participation of married women as it reduces the participation of Sinhalese and Tamil women by around 6.8 per cent in the overall model. Contrastingly, when the children are grown up (6 to 14 years), the career contribution of SL and Indian Tamil women increases. With preschool children, mothers should stay at home to engage in upbringing and caring activities by substituting the time of their market activities. When children have grown somewhat, they become capable of doing their work on their own. These consequences enable their mothers to be employed when they have young children. According to the fertility of the model of labor supply, the labor supply decisions of married women are significantly affected by fertility decisions. Fertility creates two main costs, namely direct and opportunity costs, and the husband and wife jointly take their labor market decisions while based on that. Al-Qudsi (1995) indicates that females show a lower participation rate in the labor market when they have children of school-going age. Göksel (2012) noted that, when the chances of having more children than women prefer increase, then it would reduce the opportunities for women to participate in the labor force.

Regarding the influence of the husband's level of education on the women's workforce participation; if the husband studies up to the primary level, then he is less likely to permit his wife to a paid job. In the Sinhalese and Tamil ethnic groups, if the husband studies up to the secondary level, then he is less likely to permit his wife to do a paid job. With higher educational qualifications, he would probably be able to find a better job with a higher salary which in turn leads to reducing his wife's participation. Leibowitz and Klerman (1995) documented in their examination of the dynamic effect of husbands' qualities on wives' work that, the husband's years of education too generally has a negative impact on the likelihood of a woman's employment. Further, Shah (1986) argues that there is a negative relationship between the husband's education and women's labor force participation decision.

Age increases the labor force participation of married women but at a decreasing rate as discussed by Gunathilaka (2013). There are no highlighted differences evident among ethnic groups since it is positive and highly significant in all the models. When people get older, they face many physical difficulties with some communicable and non-communicable diseases which hinder their physical and mental health and finally lead to reduce their participation. 
As expected, education functions as a good predictor that supports labor force participation of everyone and even married women are not an exception. This statement is valid among most of the ethnic groups. In some cases, even with higher educational qualifications, married women may have to stay at home due to their unavoidable family responsibilities. However, education provides a better platform to married women to participate in the job market as reaching higher educational qualifications simply leads a person to a successful career path. Nowadays, women's attitudes are changing positively towards learning. These attitudinal changes among women cause noteworthy support to increase the women's educational attainments which indirectly motivate their labor force participation. Similar findings are discussed by Samarakoon and Mayadunne (2018), Gunatilaka (2013), Abdulai and Delgado (1999), and many others.

When dealing with the subject of the spatial factors included in the model, the likelihood of participation of non-urban women is higher compared to urban women. SL and Tamil women share the highest probability level of 11 per cent as the non-urban sector is mainly organized as the plantation and agricultural economy where the majority of women take part in those employment opportunities. Especially the plantation sector employers provide basic childcare and accommodation facilities for women who engage in those dead-end jobs (tea plucking, rubber tapping, paddy harvesting, etc.). Disparities in the distribution of female-targeted employment opportunities among residential sectors are likely to be the main reason for this lower participation. One of the main reasons for the frequent decrease in FLFP within the recent past is urbanization (Ilkkaracan, 1998). Moreover, most of the employment opportunities in the non-urban area are related to the agricultural and plantation fields. Generally, women are highly skilled and specialized to perform agricultural related employment activities as an inborn characteristic in Sri Lanka. This leads to higher participation in the non-urban living sector. Another reason is, as the number of sexual harassment of women continues to rise in urban sectors, women in such sectors find it less secure to leave their homes to make their career contribution. Siddique (2018) argues that the participation of urban women in the workforce in India has declined because of increasing media reporting of sexual assaults in a person's home zone. According to the findings of Göksel (2012), females traditionally work in country regions whereas this is usually not the case in cities. Further, Samarakoon and Mayadunne (2018) have presented similar findings.

All nine provinces are significant in the overall model but distinct findings are visible in the ethno specific sub-models. When considering the Western Province as the base category, all ethnic married women who are residents in agriculture or plantation-based provinces or industrial based provinces, show a higher probability of participation. The provinces which are dominated mainly by the estate and agricultural sectors generally provide some unique job opportunities while addressing females as discussed under the nonurban sector. Samarakoon and Mayadunne (2018) explain that women in Uva Province are less likely to stay at home. Similarly, many industries like garments or apparel industries provide much more female based employments. However, women who are residents in post-war provinces share a less likelihood of participation due to the pre-market discriminations they faced during the war period and also since at present they have diminished their career contributions as a long-term impact. Samarakoon and Mayadunne (2018) too expressed similar findings.

Disabled women are less probable to participate because when women experience visual, hearing, limb, memory, communication-related difficulties and hence cannot perform their jobs effectively it tends to reduce their chances of recruitment in the job market. Further, disabled people face both market and pre-market discrimination in their personal as well as career lives as suggested by Gannon (2005). When a woman becomes vocationally trained or digitally literate, she is further strengthened, encouraged, and always welcomed to engage in the labor market by the employers and that has been proved through positive responses in the model as found by Burki and Fasih (1998).

\section{CONCLUSION}

The results of this study signify that both household and socio-economic factors have multiple positive and negative impacts on labor force participation of married women by their ethnicity. It is found that the most important reason for the lower career contribution of married women is their home environment. As the spouse of the main breadwinner of the family, they have a heavy domestic burden, family responsibilities, and obligations related to their children as well as other dependents. Their labor force contribution highly depends on their spouse's labor market behavior. However, career contribution choices are highly influenced by their ethnicity since Sri Lanka is a multi-ethnic country that follows considerable cultural beliefs and boundaries. So these cultural values and restrictions are soaked in the blood of women who live in such a country.

After a thorough investigation on marital and ethnic-specific drivers of women's labour force participation in Sri Lanka and existing policies and recommendations, some important policy recommendations are presented to manage the drivers of married FLFP in the country.

The government, as well as private sectors, can consider the complications of family arrangements (negative spillover effect from family to work), and the Ministry of Labour can introduce some part-time employment, 'working from home' or job-sharing opportunities for them. Each religion has its own set of unique merchants and business practices (Example: culinary arts, decorative products, tailoring, gardening, livestock, etc.). Ministry of Skills Development and Vocational Training can join with the Ministry of Buddhasasana, Religious and Cultural Affairs to introduce some ethno specific cultural skills development entrepreneurial programs in vocational training centers targeting each separate ethnic groups. Women should be provided with the knowledge of current digital market requirements via the Ministry of Science and Technology and Research and the Ministry of Industry and Commerce. This could facilitate such women to work from home. Micro Finance Institutions (MFIs) can join with Thrift and Credit Cooperative Services to provide microbusiness credit schemes subject to the religious restrictions for those women.

Nowadays parents are reluctant to drop their children off at day-care centers due to lack of protection and poor quality. The National Child Protection Authority can suggest to the Government to allocate a considerable amount of funds from the annual budget to build free day-care centers and crèches with reliable and high standards as a social development infrastructure for the children of working mothers at the regional level with the support of the Department of Social Services to help the working mothers in managing their 
careers. The National Child Protection Authority should form a regulatory body to ensure that the services provided by the day-care centers are of high standards and safety. The National Child Protection Authority can join with the Inland Revenue Department to provide tax concessions to the private sector organizations that provide reliable childcare services for working mothers.

Education has a positive impact on married women's career contributions and increasing educational enrolment would increase the tendency of their participation rate. The Ministry of Higher of Education can join with the Ministry of Skills Development and Vocational Training to conduct a curriculum reform to impart basic knowledge related to vocational training and entrepreneurship in the business fields from the school secondary level.

Urban sector women are less likely to participate in the workforce due to employment disparities among sectors. A similar reason is applicable to some particular provinces that could be identified as Post-War provinces. The Ministry of Skills Development and Vocational Training should consider developing courses that teach value-added productions within the existing traditional productions through vocational training centers. This would help women in creating business ideas. The Ministry of Labour can join with the Ministry of Industry and Commerce to create more female-targeted employment opportunities in the urban sector.

Disability reduces the likelihood of participation of women due to lower employment opportunities and market and pre-market discrimination. The Ministry of Skills Development and Vocational Training can introduce some disabled people to targeted course units to develop their job-related skills and attitudes. They should be taught to use their disability as an advantage. The Disability Organization Joint Front (DOJF) and Board of Investment of Sri Lanka (BOI) can join with the Ministry of Labour and the Department of Social Services to conduct awareness-raising and business advisory programmes and workshops addressing disabled people who are currently out of the labour market (beggars, those committing illegal activities, etc.). The Ministry of Skills Development and Vocational Training can join with the Ministry of Science Technology and Research and The Disability Organization Joint Front (DOJF) to introduce possible online earning course units and online career development opportunities.

Greater technical and vocational skills would increase the tendency of women's participation in the job market. The Ministry of Skills Development and Vocational Training can join with the Ministry of Science Technology and Research to introduce online earning course units and online career development opportunities (example: creating You-Tube channels, online surveys, online marketing, online investments, online graphic designing, etc.) to the vocational training centers. The Ministry of Education can join with the Ministry of Science Technology and Research in updating curriculum reforms to introduce digital literacy from the primary level of education. SMEs should be provided with the knowledge of current digital market requirements via the Ministry of Science Technology and Research and the Ministry of Industry and Commerce. The Ministry of Industry and Commerce can join with the Ministry of Science Technology and Research in creating groups and communities on social media networking sites to create links among product manufactures and product marketers.
When it comes to the knowledge contribution to the literature from this research, most of the economic theories discuss about women's labour force participation in a general context. Hardly any theories provide ethnic influence on FLFP, thus this study provides a further extension to the prevailing theories. Regarding the empirical contribution of this study, most of the recent studies have been used some common set of determinants to identify the women labour force participation in Sri Lanka. However, this study reveals some unique and chronologically relevant drivers of female job contribution that previous studies have used to a lesser extent. As an example, the influence of employment and occupational sector of the husband, current digital literacy of females, having a disabling condition, and how those factors impact on women labour force participation. Thus, this study generates a new empirical contribution to understand the ethno specific drivers of female labour force participation in the country. Further, this study uses separate binary logistic regression models for the major ethnic groups in the country on the basis of their marital status. Even though most scholars have used logit regression analysis to identify the determinants of FLFP, hardly any studies used separate models for each ethnic subgroup. Thereupon, this study satisfies this methodological gap by revealing such new methodological knowledge contribution.

This research was successfully and systematically completed using secondary microdata. However, it is subjected to some limitations which could be solved through future research directions.

The study has not derived separate econometric models for the other ethnic groups and marital statuses (divorced, separated, and widowed) due to insufficient data requirements in the survey data set. This research could be further developed using primary data for those dropped categories to have more appropriate findings.

There are some variables that should have been considered when examining the determinants of women's labour force participation, such as the impact of increasing trend of women's assaults on their career contribution, job satisfaction, quitting the career due to childbirth, and demand-side ethno specific factors' effect on women's career contribution and so on. This study did not consider those variables due to insufficient data requirements in the survey data set. However, these aspects could be explored using primary data by scholars in the future.

Further, in order to gain in-depth practical knowledge of cultural values and restrictions against women's labour force participation in their religion, a qualitative approach can be used through case studies while meeting women in each ethnic group to provide more suitable findings.

\section{Acknowledgment}

The Department of Census and Statistics in Sri Lanka should be highly acknowledged for the provision of microdata of Sri Lankan Labour Force Survey, 2018 for this study.

\section{REFERENCES}

A World Bank Group Flagship Report. (2020). The changing nature of work. World Development Report (2019), World Bank.

Aaronson, D., Dehejia, R. H., Jordan, A., Pop-Eleches, C., Samii, C., \& Schulze, K. (2017). The effect of fertility on mothers' labor supply over the last two centuries. SSRN Electronic Journal. https:// doi.org/10.2139/ssrn.2915334

Abdulai, A., \& Delgado, C. L. (1999). Determinants of nonfarm earnings of farm-based husbands and wives in Northern Ghana. American Journal of Agricultural Economics, 81(1), 117-130. https://doi.org/10.2307/1244455 
Abraham, A. Y., Ohemeng, F. N. A., \& Ohemeng, W. (2017). Female labour force participation: Evidence from Ghana. International Journa of Social Economics, 44(11), 1489-1505. https://doi.org/10.1108/IJSE-06-2015-0159

Ajwad, I. M., \& Kurukulasuriya, P. (2002). Ethnic and gender wage disparities in Sri Lanka. The World Bank. http://crossasia-repository.ub.uni-heidelberg.de/3637/1/Ethnic\%20Gender\%20Wage\%20Sri\%20Lanka.pdf

Al-Qudsi, S. S. (1995). Labour participation of Arab women: Estimates of the fertility to labour supply link. Applied Economics, 30(7), 931-941.

Arellano, M., \& Meghir, C. (1992). Female labour supply and on-the-job search: An empirical model estimated using complementary data sets. Review of Economic Studies, 59(3), 537-557. https://doi.org/10.2307/2297863

Azid, T., Aslam, M., \& Chaudhary, M. O. (2001). Poverty, female labour force participation and cottage industry: A case study of cloth embroidery in Rural Multan. Pakistan Development Review, 40(4 PART II), 1105-1118. https://doi.org/10.30541/v40i4iipp.1105-1118

Barro, R. J. (1998). Human capital and growth in cross-country regressions. Harvard University. http://citeseerx.ist.psu.edu/viewdoc/download? https://doi=10.1.1.562.9470\&rep=rep1\&type=pdf

Baxter, J. (1997). Gender equality and participation in housework: A cross-national perspective. Journal of Comparative Family Studies, 220-247.

Becker, G. S. (1965). A Theory of the Allocation of Time. The economic journal, 493-517.

Becker, G. S. (1973). A Theory of Marriage: Part 1. Journal of Political Economy, 81(4), 813-846.

Bombuwela, P. M., \& De Alwis, A. C. (2013). Effects of glass ceiling on women career development in private sector organizations - case of Sri Lanka. Journal of Competitiveness, 5(2). https://doi.org/10.7441/joc.2013.02.01

Burki, A. A., \& Fasih, T. (1998). Household' non-leisure time allocation for children and determinants of child labour in Punjab, Pakistan. $\mathrm{Pa}$ kistan Development Review, 38(4), 899-914.

Chaudhary, R., \& Verick, S. (2014). Female labour force participation in India and beyond. ILO Asia-Pacific Working Paper Series, 1-48.

Contreras, D., Puentes, E., \& Bravo, D. (2005). Female labour force participation in greater Santiago, Chile: 1957-1997. A synthetic cohor analysis. Journal of International Development, 17(2), 169-186.

Das, M. B., \& Desai, S. (2003). Why educated women are less likely to be employed in India: Testing competing hypotheses. Social Protection Discussion Paper Series, Human Development Network, The World Bank, 0313.

Department of Census and Statistics. (2019). Sri Lanka Labour Force Survey. Annual Report (2018).

Ejaz, M. (2007). Determinants of female labor force participation in $\mathrm{Pa}$ kistan: An empirical analysis of PSLM (2004-05) microdata. The La hore Journal of Economics, 12(1), 203-235.

Faridi, M. Z., Chaudhry, I. S., \& Anwar, M. (2009). The socio-economic and demographic determinants of women work participation in Pakistan: Evidence from Bahawalpur District. Journal of South Asian Studies, 24(2), 353-369.

Gannon, B. (2005). A dynamic analysis of disability and labour force participation in Ireland 1995-2000. Health Economics, 14(9), 925-938. https://doi.org/10.1002/hec.1044

Göksel, I. (2012). The reasons of decreasing trend of female labour force participation in Turkey: The role of conservatism. Working Papers in Economics, 12(05).

Gunatilaka, R. (2013). To work or not to work? Factors holding women back from market work in Sri Lanka. International Labour Organization, ILO DWT for South Asia and Country Office for India.

Gunatilaka, R., \& Vithanagama, R. (2018). Women's labour force participation in Sri Lanka's North. Grow Working Paper Series. http://grow.research.mcgill.ca/publications/working-papers/gwp2018-18.pd

Horrell, S., \& Humphries, J. (1995). Women's labour force participation and the transition to the male-breadwinner family, 1790-1865. The Economic History Review, 48(1), 89-117. https://doi.org/10.1111/j.1468-0289.1995.tb01410.x
Hussain, I., Rabbi, F., \& Ali, S. (2012). The determinants of female participation in paid jobs: The case of Three Pakhtun's Communities in Khyber Pakhtunkhwa, Pakistan. Journal of Economic and Social Research, 14(1), 73-90.

Ilkkaracan, P. (1998). Exploring the context of women's sexuality in Eastern Turkey. Reproductive Health Matters, 6(12), 66-75. https://www.tandfonline.com/doi/pdf/10.1016/S0968 8080\%2898\%2990009-X

International Labour Organization. (2016). Women at Work: Trends 2016 - Executive Summary, 42(12), 123 -135.

International Labour Organization Statistics. (2020). Social Finance - Annual Report 2019.

Jaeger, U. (2010). Working or stay-at-home mum? The influence of family benefits and religiosity. ifo Working Paper, 84 . https://www.econstor.eu/bitstream/10419/73800/1/IfoWorkingPaper-84.pdf

Khan, R. E. A., \& Khan, T. (2009). Labor force participation of married women in Punjab (Pakistan). International Journal of Social Economics, 37(8), 592-612. Doi.org/10.1108/03068291011060643

Klasen, S. (2002). Low schooling for girls, slower growth for all? Crosscountry evidence on the effect of gender inequality in education on economic development. The World Bank Economic Review, 16(3), 345-373. https://doi: 10.1093/wber/lhf004

Kulatunga, S. T. (2014). Household Entitlements in the Eastern Province of Sri Lanka: With Special Reference to Female Headed Households [Conference session]. Sri Lanka Economics Research Conference SLERC-2014, Sri Lanka, Volume III, 257.

Leibowitz, A., \& Klerman, J. A. (1995). Explaining changes in married mothers' employment over time. Demography, 32(3), 365-378.

Madurawala, D. S. (2009). Labour force participation of women in childbearing ages, Sri Lanka. Sri Lanka Journal of Population Studies, 11, 01-38.

Mason, K. O., Czajka, J. L., \& Arber, S. (1976). Change in US women's sexrole attitudes, 1964-1974. American Sociological Review, 573-596.

Michalopoulos, C., Robins, P. K., \& Garfinkel, I. (1992). A structural model of labour supply and child care demand. Journal of Human Resources, 166-203. https://www.jstor.org/stable/145916

Naqvi, Z. F., \& Shahnaz, L. (2002). How do women decide to work in Pakistan? Pakistan Development Review, 41(4 PART 2), 495-513. https://doi.org/10.30541/v41i4iipp.495-513

Palma, P. D. (2001). Why women avoid computer science. Communications of the ACM, 44(6), 27-30. http://cs.furman.edu/ ktreu/csc101/docs/17women.pdf

Panda, P. K. (2003). Poverty and young women's employment: linkages in Kerala. Economic and Political Weekly, 54(2), 4034-4042.

Pastore, F., \& Tenaglia, S. (2013). Ora et non Labora ? A test of the impact of religion on female labor supply. IZA Discussion Paper Series, 7356(7356), 1-39.

Samarakoon, S. J. M. N. G., \& Mayadunne, G. (2018). An exploratory study on low labour force participation of women in Sri Lanka. Sri Lanka Journal of Social Sciences, 41(2), 137-151. https://doi.org/10.4038/sljss.v41i2.7701

Sarvananthan, M., Suresh, J., \& Alagarajah, A. (2017). Feminism, nationalism and labour in post-civil war Northern Province of Sri Lanka. Development in Practice, 27(1), 122-128. https://doi.org/10.1080/09614524.2017.1257566

Semasinghe, W. M. (2017). Women's labour force participation in Sri Lanka: An inquiry into the factors influencing women's participation in the labour market. International Journal of Social Science and Humanity, 7(3), 184-187.

Shah, N. M. (1986). Changes in female roles in Pakistan: Are the volume and pace adequate? Pakistan Development Review, 25(3), 339-369. https://doi.org/10.30541/v25i3pp.339-369

Siddique, Z. (2018). Violence and female labor supply. IZA Working Paper, $\quad 11874 . \quad$ https://www.econstor.eu/bistream/10419/185334/1/dp11874.pdf

Tansel, A. (1998). Economic development and female labor force participation in turkey: Time-series evidence and cross-province estimates. ERF Working Paper Series, 0124.

https://erf.org.eg/publication cat/working-paper-series/ 
Thornton, A., \& Freedman, D. (1979). Changes in the sex-role attitudes of women, 1962-1977: Evidence from a panel study. American Sociological Review, 831-842. https://isr.umich.edu/wp-content/uploads/historicPublications/Changesin_5657_.PDF

Trauth, E. M. (2002). Odd girl out: An individual different perspective on women in the IT profession. Information Technology \& People, 15(2). https://doi: 10.1108/09593840210430552

Van Hedel, K., Van Lenthe, F. J., Avendano, M., Bopp, M., Esnaola, S., Kovacs, K., \& Mackenbach, J. P. (2015). Marital status, labour force activity and mortality: A study in the USA and six European countries.
Scandinavian journal of public health, 43(5), 469-480. https://doi.10.1177/1403494815578947

Weerasinghe, D. P., \& Parr, N. J. (2002). Effect of wealth on marital fertility in Sri Lanka. Journal of Health Population and Nutrition, 20(2), 112-119. https://doi.org/10.3329/jhpn.v20i2.135

World Economic Forum. (2016). Annual Report 2016 - 2017

Wilson-Kovacs, D. M., Ryan, M., \& Haslam, A. (2006). The glass-cliff: women's career paths in the UK private IT sector. Equal Opportunities International, 25(8),

674-687. https://doi/10.1108/02610150610719137/full/html

\section{Appendices}

Appendix 1: Descriptive statistics for the sample of married women's labour force participation

\begin{tabular}{|c|c|c|c|c|c|c|c|c|}
\hline \multirow{3}{*}{ Factors and variables } & \multicolumn{2}{|c|}{ Model 1} & \multicolumn{2}{|c|}{ Model 2} & \multicolumn{2}{|c|}{ Model 3} & \multicolumn{2}{|c|}{ Model 4} \\
\hline & \multicolumn{2}{|c|}{ Overall model } & \multicolumn{2}{|c|}{ Sinhalese } & \multicolumn{2}{|c|}{$\begin{array}{l}\text { SL and Ind } \\
\text { Tamil }\end{array}$} & \multicolumn{2}{|c|}{ Moor } \\
\hline & $\begin{array}{r}\text { Mean/ } \\
\text { Proportion }\end{array}$ & $\begin{array}{l}\text { Std. } \\
\text { Dev }\end{array}$ & $\begin{array}{r}\text { Mean/ } \\
\text { Proportion }\end{array}$ & $\begin{array}{l}\text { Std. } \\
\text { Dev }\end{array}$ & $\begin{array}{r}\text { Mean/ } \\
\text { Proportion }\end{array}$ & $\begin{array}{l}\text { Std. } \\
\text { Dev }\end{array}$ & $\begin{array}{r}\text { Mean/ } \\
\text { Proportion }\end{array}$ & $\begin{array}{l}\text { Std. } \\
\text { Dev }\end{array}$ \\
\hline No. obs: & \multicolumn{2}{|c|}{14533} & \multicolumn{2}{|c|}{10196} & \multicolumn{2}{|c|}{2788} & \multicolumn{2}{|c|}{1404} \\
\hline $\begin{array}{l}\text { Married women labour force par- } \\
\text { ticipation (Dy) }\end{array}$ & 0.352 & 0.477 & 0.390 & 0.487 & 0.312 & 0.463 & 0.161 & 0.368 \\
\hline \multicolumn{9}{|l|}{ Ethnicity } \\
\hline Sinhalese (Dref) & 0.705 & 0.455 & N/A & $\mathrm{N} / \mathrm{A}$ & $\mathrm{N} / \mathrm{A}$ & $\mathrm{N} / \mathrm{A}$ & $\mathrm{N} / \mathrm{A}$ & $\mathrm{N} / \mathrm{A}$ \\
\hline SL and Indian Tamil $\left(D_{1}\right)$ & 0.195 & 0.396 & N/A & $\mathrm{N} / \mathrm{A}$ & $\mathrm{N} / \mathrm{A}$ & $\mathrm{N} / \mathrm{A}$ & $\mathrm{N} / \mathrm{A}$ & $\mathrm{N} / \mathrm{A}$ \\
\hline $\operatorname{Moor}\left(D_{2}\right)$ & 0.097 & 0.296 & N/A & $\mathrm{N} / \mathrm{A}$ & $N / A$ & N/A & $\mathrm{N} / \mathrm{A}$ & $\mathrm{N} / \mathrm{A}$ \\
\hline \multicolumn{9}{|l|}{ Household Factors } \\
\hline Household size (X1) & 4.064 & 1.427 & 3.947 & 1.343 & 4.210 & 1.484 & 4.614 & 1.717 \\
\hline Family Income (X2) & 33.53 & 152.2 & 33.16 & 138.4 & 0.031 & 0.188 & 35.50 & 73.29 \\
\hline \multicolumn{9}{|l|}{ Employment sector of husband } \\
\hline Employer (Dref) & 0.037 & 0.189 & 0.034 & 0.181 & 0.033 & 0.178 & 0.067 & 0.250 \\
\hline Employee $\left(D_{3}\right)$ & 0.419 & 0.493 & 0.404 & 0.490 & 0.470 & 0.499 & 0.411 & 0.492 \\
\hline Own account worker $\left(D_{4}\right)$ & 0.361 & 0.480 & 0.372 & 0.483 & 0.316 & 0.465 & 0.372 & 0.483 \\
\hline Non-paid family worker $\left(D_{5}\right)$ & 0.004 & 0.066 & 0.005 & 0.071 & $\mathrm{~N} / \mathrm{A}$ & $\mathrm{N} / \mathrm{A}$ & $N / A$ & $\mathrm{~N} / \mathrm{A}$ \\
\hline \multicolumn{9}{|l|}{ Occupational sector of husband } \\
\hline Managerial sector $\left(D_{6}\right)$ & 0.078 & 0.268 & 0.073 & 0.260 & 0.067 & 0.250 & 0.137 & 0.344 \\
\hline Professional $\left(D_{7}\right)$ & 0.027 & 0.162 & 0.025 & 0.158 & 0.031 & 0.173 & 0.032 & 0.176 \\
\hline Technician (D8) & 0.056 & 0.230 & 0.059 & 0.236 & 0.040 & 0.196 & 0.064 & 0.246 \\
\hline Clerical (D9) & 0.015 & 0.122 & 0.015 & 0.125 & 0.012 & 0.111 & $\mathrm{~N} / \mathrm{A}$ & $\mathrm{N} / \mathrm{A}$ \\
\hline Agricultural $\left(D_{10}\right)$ & 0.179 & 0.384 & 0.196 & 0.397 & 0.168 & 0.374 & 0.091 & 0.288 \\
\hline Service (Dref) & 0.066 & 0.249 & 0.063 & 0.243 & 0.054 & 0.227 & 0.111 & 0.314 \\
\hline Production $\left(D_{11}\right)$ & 0.221 & 0.414 & 0.233 & 0.423 & 0.176 & 0.381 & 0.220 & 0.414 \\
\hline Elementary $\left(D_{12}\right)$ & 0.173 & 0.378 & 0.143 & 0.350 & 0.270 & 0.444 & 0.183 & 0.386 \\
\hline Unidentified $\left(D_{13}\right)$ & 0.004 & 0.065 & 0.005 & 0.075 & $\mathrm{~N} / \mathrm{A}$ & N/A & $\mathrm{N} / \mathrm{A}$ & $\mathrm{N} / \mathrm{A}$ \\
\hline \multicolumn{9}{|l|}{ Availability of Children } \\
\hline $\begin{array}{l}\text { Having children less than } 6 \text { years } \\
\left(D_{14}\right)\end{array}$ & 0.188 & 0.390 & 0.171 & 0.377 & 0.196 & 0.397 & 0.274 & 0.446 \\
\hline Having children 6 to 14 years $\left(D_{15}\right)$ & 0.388 & 0.487 & 0.371 & 0.483 & 0.404 & 0.490 & 0.475 & 0.499 \\
\hline $\begin{array}{l}\text { Having children more than } 15 \\
\text { years old }\left(D_{16}\right)\end{array}$ & 0.550 & 0.497 & 0.551 & 0.497 & 0.543 & 0.498 & 0.563 & 0.496 \\
\hline Having a domestic servant (D17) & 0.003 & 0.058 & 0.003 & 0.060 & $\mathrm{~N} / \mathrm{A}$ & $\mathrm{N} / \mathrm{A}$ & $\mathrm{N} / \mathrm{A}$ & $\mathrm{N} / \mathrm{A}$ \\
\hline \multicolumn{9}{|l|}{ Education of husband } \\
\hline Primary $\left(D_{18}\right)$ & 0.199 & 0.399 & 0.172 & 0.377 & 0.289 & 0.453 & 0.213 & 0.410 \\
\hline Secondary $\left(D_{19}\right)$ & 0.746 & 0.435 & 0.776 & 0.416 & 0.645 & 0.478 & 0.733 & 0.442 \\
\hline Tertiary $\left(D_{20}\right)$ & 0.033 & 0.178 & 0.035 & 0.184 & 0.031 & 0.173 & 0.026 & 0.160 \\
\hline \multicolumn{9}{|l|}{ Socio Economic Factors } \\
\hline Age $\left(X_{3}\right)$ & 48.31 & 12.55 & 49.20 & 12.49 & 46.92 & 12.54 & 44.93 & 12.00 \\
\hline Age square $\left(X_{4}\right)$ & 2491 & 1253 & 2577 & 1268 & 2360 & 1223 & 2163 & 1106 \\
\hline Educational attainment $\left(\mathrm{X}_{4}\right)$ & 9.159 & 3.650 & 9.644 & 3.459 & 7.994 & 3.908 & 8.034 & 3.679 \\
\hline Living sector $\left(D_{21}\right)$ & & & & & & & & \\
\hline Non-urban & 0.838 & 0.367 & 0.866 & 0.339 & 0.822 & 0.382 & 0.683 & 0.465 \\
\hline Province & & & & & & & & \\
\hline $\begin{array}{l}\text { Agriculture or plantation base } \\
\text { provinces }\left(D_{22}\right)\end{array}$ & 0.342 & 0.474 & 0.393 & 0.488 & 0.214 & 0.410 & 0.225 & 0.418 \\
\hline Industrial base provinces $\left(D_{23}\right)$ & 0.239 & 0.426 & 0.310 & 0.462 & 0.023 & 0.152 & 0.159 & 0.366 \\
\hline Post-war provinces $\left(D_{24}\right)$ & 0.199 & 0.399 & 0.031 & 0.175 & 0.694 & 0.460 & 0.440 & 0.496 \\
\hline Disability $\left(D_{25}\right)$ & 0.162 & 0.369 & 0.163 & 0.369 & 0.163 & 0.369 & 0.158 & 0.365 \\
\hline Digital literacy $\left(D_{26}\right)$ & 0.232 & 0.422 & 0.239 & 0.426 & 0.202 & 0.401 & 0.237 & 0.425 \\
\hline Technical training $\left(D_{27}\right)$ & 0.060 & 0.237 & 0.071 & 0.258 & 0.034 & 0.181 & 0.025 & 0.158 \\
\hline
\end{tabular}

Notes:

1. (D), (Dref) and (X) indicate the dummy and reference category and continuous variables respectively.

2. For the dummy variables, proportions are presented only for the categories that equal to one.

Source: Developed by the researcher using LFS 2018 data 
